


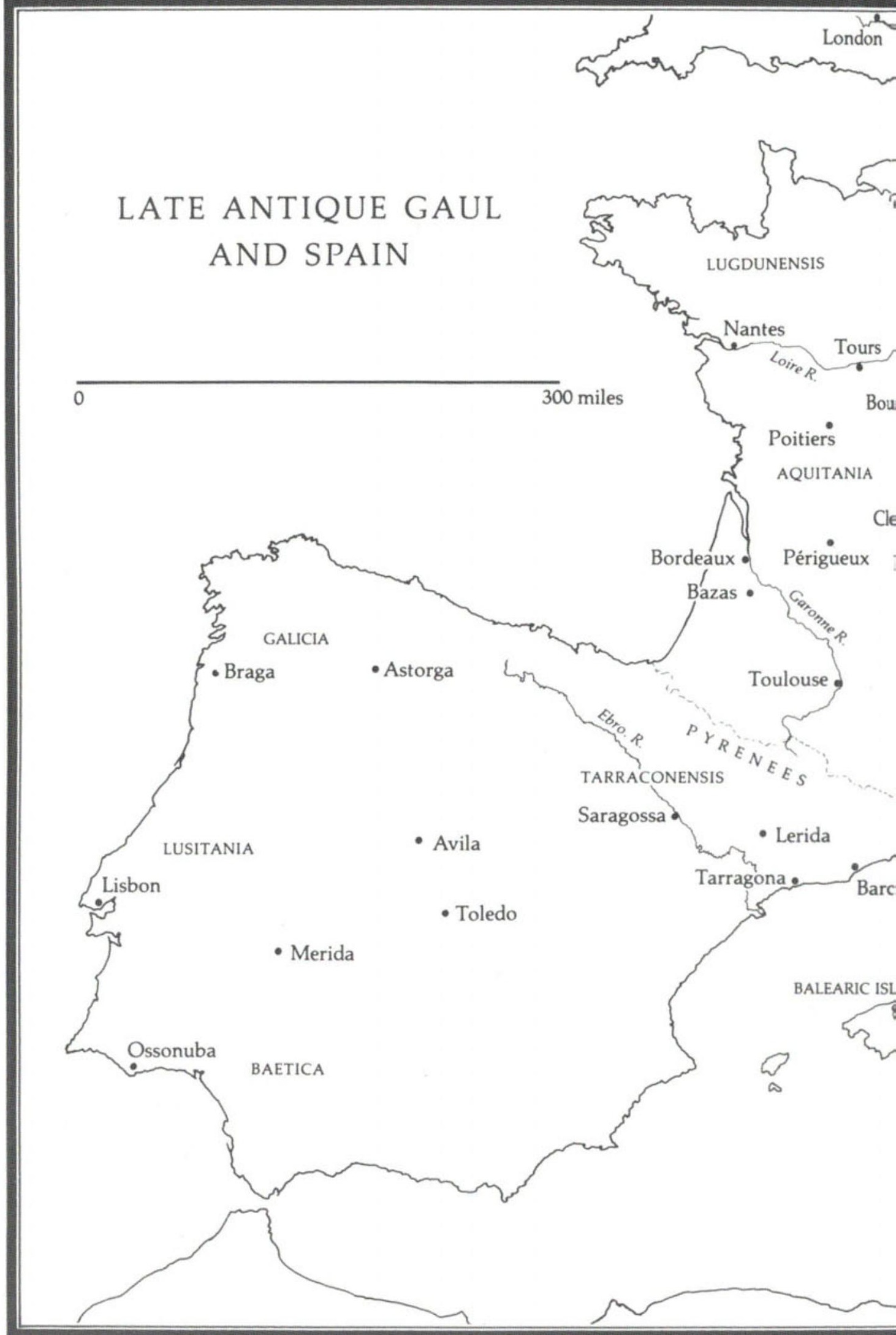




\title{
RISTES
}

\section{THE TRANSFORMATION OF THE}

\section{CLASSICAL HERITAGE}

\author{
Peter Brown, General Editor
}

I

Art and Ceremony in Late Antiquity

by Sabine G. MacCormack

II

Synesius of Cyrene: Philosopher-Bishop

by Jay Alan Bregman

III

Theodosian Empresses: Women and Imperial Dominion in Late Antiquity

by Kenneth G. Holum

IV

John Chrysostom and the Jews: Rhetoric and Reality in the Late Fourth Century

by Robert L. Wilken

$\mathrm{V}$

Biography in Late Antiquity: A Quest

for the Holy Man

by Patricia Cox

VI

Pachomius: The Making of a Community

In Fourth-Century Egypt

by Philip Rousseau

VII

Change in Byzantine Culture in the Eleventh and Twelfth Centuries

by A. P. Kazhdan and Ann Wharton Epstein

VIII

Leadership and Community in Late Antique Gaul

by Raymond Van Dam 
LEADERSHIP AND COMMUNITY IN LATE ANTIQUE GAUL 



\section{RAYMOND VAN DAM}

Leadership and Community in Late Antique Gaul 


\section{University of California Press}

Berkeley and Los Angeles, California

University of California Press, Ltd.

London, England

$$
\text { (C) } 1985 \text { by }
$$

The Regents of the University of California

Library of Congress Cataloging in Publication Data Van Dam, Raymond.

Leadership and community in late antique Gaul. Bibliography: $p$.

Includes index.

1. Gaul-58 B.C. -511 A.D. 2. Merovingians-History.

I. Title.

DC62.v36 $1985 \quad 936.4 \quad 83-24321$

ISBN 0-520-05162-9

Printed in the United States of America

123456789 
For three teachers, three friends:

BERT VANDER LEE

BOB OTTEN

DICK WHITTAKER 
